\title{
SYNTHESIS OF BENZOXAZEPINE DERIVATIVES FROM PYRAZOLE-CHALCONE VIA A SIMPLE AND CONVENIENT PROTOCOL USING BASIC ALUMINA AS SOLID SUPPORT
}

\author{
D. ASHOK*I, G. RADHIKA', BODDU ANANDA RAO ${ }^{1}$, M. SARASIJA ${ }^{1}$, \\ A. JAYASHREE ${ }^{2}$ AND P. SADANANDAM \\ ${ }^{1}$ Green and Medicinal Chemistry Laboratory, Department of Chemistry, Osmania University, Hyderabad, 500007, India. \\ ${ }^{2}$ Centre for Chemical Sciences \& Technology, JNTU-H, Hyderabad, 500085, India.
}

\begin{abstract}
In the present study a series of novel benzoxazepine (5a-h) derivatives were synthesized by the thermal cyclization reaction of various pyrazole-chalcones (3a-h) with 2-aminophenol, by conventional heating and microwave irradiation $(180 \mathrm{~W})$ in solvent-free conditions in short reaction times (9-12 min), giving high yields of products $(80-88 \%)$. The homogeneity of all the newly synthesized compounds has been checked by TLC. Their IR, NMR, ESI-mass spectral data and elemental analysis are in accord with the assigned structure. The title compounds were evaluated for their antibacterial activity against Gram-positive bacteria Staphylococcus aureus, Bacillus subtilis, and Gram-negative bacteria Pseudomonas aeruginosa, Escherichia coli. Compounds $\mathbf{3 c}$, $\mathbf{3 h}$, $\mathbf{5 b}$, 5c, 5g and $\mathbf{5 h}$ were found to show good antibacterial activity when compared with that of standard drug Ampicillin. Furthermore, the same library of compounds were evaluated for antifungal activity against Aspergillus nigerzeae, Penicillium italicum and Fusarium oxysporum using Grieseofulvin as standard drug. The results of the above studies show that the compounds $\mathbf{3 b}, \mathbf{3 c}, \mathbf{3 e}, \mathbf{3 h}, \mathbf{5 a}, \mathbf{5 c}, \mathbf{5} \mathbf{g}$ and $\mathbf{5 h}$ showed good antifungal activity against all the tested organisms
\end{abstract}

Keywords: Pyrazole, Chalcone, benzoxazepine, microwave irradiation, basic alumina.

\section{INTRODUCTION}

The prominence in attaining chalcones has numerous applications in the field of pharmaceutics and also in the production of pesticides, cosmetics ${ }^{1,2}$. Chalcone and its functionalized derivatives display diverse pharmacological properties have been discovered as, antimicrobial ${ }^{3-8}$, antitubercular ${ }^{3,9,10}$, anticancer $^{10,11}$, anti-inflammatory ${ }^{10}$, and antioxidant ${ }^{7}$ activities. Chalcones bear very good synthon framework so that variety of novel heterocycles with good pharmaceutical profile can be designed. On the other hand, pyrazoles represent a key motif in heterocyclic chemistry and occupy a prime place in medicine and pesticide chemistry due to their capability to exhibit a wide range of bioactivities such as antimicrobial, anti-inflammatory, anticancer and antiviral $^{12-15}$. Pyrazoles were found to possess inhibitory activities against XO, cyclooxygenase, and alkaline phosphatases ${ }^{16,17}$. Benzoxazepine derivatives are prevalent designs of biologically active compounds ${ }^{18,19}$. These derivatives are well-known pharmacophores showing capable properties against various diseases such as antipsychotic ${ }^{20}$, central nervous system damage ${ }^{21}$ and anticancer activities ${ }^{22}$. Usually, benzoxazepine derivatives preparation involves multistep synthesis ${ }^{23-25}$. Therefore, an efficient, eco-friendly, straightforward synthetic method toward benzoxazepine still represents an interesting assignment for chemists.

The science of green chemistry was developed to chance the increasing demand for environmentally gentle chemical practices. Solvent free synthesis has received considerable attention in recent years. Microwave heating has a prominence in the search for green synthesis ${ }^{26}$. Microwave irradiation conditions extensively reduce reaction time without promoting any side reactions ${ }^{27,28}$. Alumina like solid support, holds excellent capability to absorb the organic compounds on their surface, and transmits microwave irradiation. Previous reports have also shown that the basic oxides, like alumina, assist as a good alternative for catalyzed heteroannulation reactions due to its character as a base ion in the solid framework ${ }^{29}$. This provoked us to discover an efficient yet simple and one-pot green protocol using basic alumina as solid support in microwave irradiation.

In the current study, we aimed to obtain new compounds containing both pyrazole and benzoxazepine rings in the same structure, via the cyclocondensation reaction, solvent free microwave irradiation conditions. This nonconventional protocol offers several applications such as simple procedure, fast reaction conditions and good yields as compared to conventional methods. It involves the exposure of neat reactants to give high yields of pure products, easy work-up, low cost and economical. The use of basic alumina as a solid support assists and it eliminates the use of $\mathrm{K}_{2} \mathrm{CO}_{3}$ and ethanol solvent. Herein, we have shown (Scheme 1) the synthesis of benzoxazepines derivatives from pyrazole-chalcone reaction with 2-amino phenol, basic alumina as a solid support using as a catalyst under microwave irradiation $(180 \mathrm{~W})$. In all reactions the products were achieved in high yield. Chemical structures of compounds were confirmed by IR, ${ }^{1} \mathrm{H}$ NMR, ${ }^{13} \mathrm{C}$ NMR, ESI-MS, spectral data and elemental analysis.

\section{EXPERIMENTAL}

All the melting points were determined in open capillary tubes and are uncorrected. The purity of the compounds was checked by TLC on silica gel $60 \mathrm{~F}_{254}$ (Merck). ${ }^{1} \mathrm{H}$ NMR and ${ }^{13} \mathrm{C}$ NMR spectra were recorded on Avance 400 spectrometer using $\mathrm{CDCl}_{3}$ solvent TMS as an internal standard. IR spectra were recorded in $\mathrm{KBr}$ Shimadzu FTIR 8400 S spectrophotometer. Mass spectra were recorded on LCMS-2010A Shimadzu spectrophotometer. Elemental analysis was determined by using the EA1112 Thermofinnigan CHNS analyzer. Microwave reactions were carried out in a Multisynth series microwave system (Milestone).

Conventional heating method (A)

A mixture of chalcone (3a-h) [30] (0.01mol), 2-amino phenol (7) (0.01 mol) were dissolved in $10 \mathrm{ml}$ of ethanol and to this $\mathrm{K}_{2} \mathrm{CO}_{3}(2 \mathrm{~g})$ was added. The contents were refluxed for appropriate time mentioned in Table-1. The progress of the reaction was monitored by TLC. After completion of the reaction, the mixture was cooled to room temperature and poured into water. The product was extracted with acetone and was recrystalized with acetone to afford pure compounds (5a-h).

Microwave irradiation method $(B)$

A mixture of chalcone (3a-h) $(0.01 \mathrm{~mol}), 2$-amino phenol (7) $(0.01 \mathrm{~mol})$ was adsorbed on basic alumina $(3 \mathrm{~g})$. The adsorbed material was taken in a quartz tube and inserted into the Teflon vial with screw capped and then subjected to microwave irradiation for an appropriate given time in Table-1. After completion of the reaction, cooled to room temperature and the product was extracted with acetone and was recrystalized with acetone to afford pure compounds (5a-h).

2-((E)-2,3-dihydro-2-(1,3-diphenyl-1H-pyrazol-4-yl)benzo[b][1,4] oxazepin-4-yl)phenol (5a)

White solid; IR spectrum, $v \mathrm{~cm}^{-1}: 3135(\mathrm{OH}), 1607(\mathrm{C}=\mathrm{N}), 1238(\mathrm{C}-\mathrm{O}-\mathrm{C})$. ${ }^{1} \mathrm{HNMR}$ spectrum, $\delta$, ppm: $8.12(\mathrm{~s}, 1 \mathrm{H}$, pyrazole-H), $7.98-6.99(\mathrm{~m}, 18 \mathrm{H}$, Ar-H), $5.67\left(\mathrm{dd}, 1 \mathrm{H}, J_{\mathrm{xp}}=12.4 \mathrm{H}_{7}, J_{\mathrm{xA}}=3.2 \mathrm{H}_{\mathrm{z}}\right), 3.24\left(\mathrm{dd}, 1 \mathrm{H}, J_{\mathrm{BA}}=16.8 \mathrm{H}_{z}\right.$, $\left.J_{\mathrm{BX}}=12.4 \mathrm{H}_{\mathrm{Z}}\right), 3.04\left(\mathrm{dd}, 1 \mathrm{H}, J_{\mathrm{AB}}=16.8 \mathrm{H}_{\mathrm{Z}} J_{\mathrm{AX}}=3.2 \mathrm{H}_{\mathrm{Z}}\right) .{ }^{13} \mathrm{CNMR}$ spectrum, $\delta_{\mathrm{C}}$, ppm: $154.5,152.1,147.3,139.8,133,129.5,128.7,128.6,128.3,128.2,126.7$, $126.1,125.7,124.9,124.7,124,123.2,120.3,119.5,119.2,112.5,70,42.5$. Found, \%: C 78.71; $\mathrm{H}$ 5.04; $\mathrm{N}$ 9.23. $\mathrm{C}_{30} \mathrm{H}_{23} \mathrm{~N}_{3} \mathrm{O}_{2}$. Calculated, \%: C 78.75; $\mathrm{H}$ 5.07; N 9.18. MS: $458[\mathrm{M}+\mathrm{H}]^{+}$. 
J. Chil. Chem. Soc., 63, No 2 (2018)

Table 1: Conventional heating and Microwave irradiation optimization for the synthesis of $\mathbf{5 a - h}$.

\begin{tabular}{|c|c|c|c|c|c|c|}
\hline \multirow{2}{*}{$\begin{array}{l}\text { Compound } \\
\text { Number }\end{array}$} & \multirow{2}{*}{$\begin{array}{c}\text { Molecular Formula } \\
\text { (Mol. Wt) }\end{array}$} & \multirow{2}{*}{ M.P. $\left({ }^{\circ} \mathrm{C}\right)$} & \multicolumn{2}{|c|}{ Conventional heating (A) } & \multicolumn{2}{|c|}{ Microwave irradiation (B) } \\
\hline & & & Time (h) & Yield (\%) & Time (min) & Yield (\%) \\
\hline $5 \mathbf{a}$ & $\mathrm{C}_{30} \mathrm{H}_{23} \mathrm{~N}_{3} \mathrm{O}_{2}(457)$ & $180-182$ & 6 & 60 & 9 & 85 \\
\hline $5 \mathbf{b}$ & $\mathrm{C}_{31} \mathrm{H}_{25} \mathrm{~N}_{3} \mathrm{O}_{2}(471)$ & $193-195$ & 8 & 62 & 10 & 83 \\
\hline $5 c$ & $\mathrm{C}_{31} \mathrm{H}_{25} \mathrm{~N}_{3} \mathrm{O}_{3}(487)$ & $188-190$ & 8 & 70 & 10 & 85 \\
\hline $5 d$ & $\mathrm{C}_{30} \mathrm{H}_{22} \mathrm{ClN}_{3} \mathrm{O}_{2}(491)$ & $176-178$ & 8 & 68 & 12 & 80 \\
\hline $5 e$ & $\mathrm{C}_{30} \mathrm{H}_{22} \mathrm{BrN}_{3} \mathrm{O}_{2}$ & $222-224$ & 9 & 65 & 9 & 88 \\
\hline $5 f$ & $\mathrm{C}_{30} \mathrm{H}_{22} \mathrm{BrN}_{3} \mathrm{O}_{2}(535)$ & $254-256$ & 9 & 62 & 9 & 85 \\
\hline $5 \mathrm{~g}$ & $\mathrm{C}_{31} \mathrm{H}_{24} \mathrm{BrN}_{3} \mathrm{O}_{2}(549)$ & $226-268$ & 7 & 60 & 10 & 80 \\
\hline $5 \mathbf{h}$ & $\mathrm{C}_{31} \mathrm{H}_{24} \mathrm{BrN}_{3} \mathrm{O}_{3}(565)$ & $252-254$ & 8 & 62 & 9 & 82 \\
\hline
\end{tabular}

2-((E)-2,3-dihydro-2-(1-phenyl-3-p-tolyl-1H-pyrazol-4-yl)benzo[b][1,4] oxazepin-4-yl)phenol ( 5 b)

White solid; IR spectrum, $v \mathrm{~cm}^{-1}: 3141(\mathrm{OH}), 1611(\mathrm{C}=\mathrm{N}), 1231(\mathrm{C}-\mathrm{O}-\mathrm{C})$. ${ }^{1} \mathrm{HNMR}$ spectrum, $\delta$, ppm: $8.13(\mathrm{~s}, 1 \mathrm{H}$, pyrazole-H $), 7.98-7.07(\mathrm{~m}, 17 \mathrm{H}, \mathrm{Ar}-\mathrm{H})$ $5.67\left(\mathrm{dd}, 1 \mathrm{H}, J_{\mathrm{XB}}=12.4 \mathrm{H}_{\mathrm{Z}}, J_{\mathrm{XA}}=2.8 \mathrm{H}_{\mathrm{Z}}\right), 3.22\left(\mathrm{dd}, 1 \mathrm{H}, J_{\mathrm{BA}}=16.8 \mathrm{H}_{\mathrm{Z}}, J_{\mathrm{BX}}=12.4 \mathrm{H}_{\mathrm{Z}}\right)$,

$3.01\left(\mathrm{dd}, 1 \mathrm{H}, J=16.8 \mathrm{H}_{\mathrm{z}} J_{\mathrm{x}}=2.8 \mathrm{H}_{\mathrm{z}}\right), 2.41\left(\mathrm{~s}, 3 \mathrm{H}, \mathrm{CH}_{3}\right) \cdot{ }^{13} \mathrm{CNMR}$ spectrum, $\delta_{\mathrm{C}}$, ppm: $161.4,152.2,140.3,138.4,136.1,129.5,129.4,128.5,127.3,126.8$, $121.8,121.6,119.7,119.6,119.3,118.2,72.4,43.8,21.8$. Found, \%: C 78.93 $\mathrm{H}$ 5.32, $\mathrm{N}$ 8.94. $\mathrm{C}_{31} \mathrm{H}_{25} \mathrm{~N}_{3} \mathrm{O}$. Calculated, \%: C 78.96; H 5.34; N 8.91. MS: 472 $[\mathrm{M}+\mathrm{H}]^{+}$.

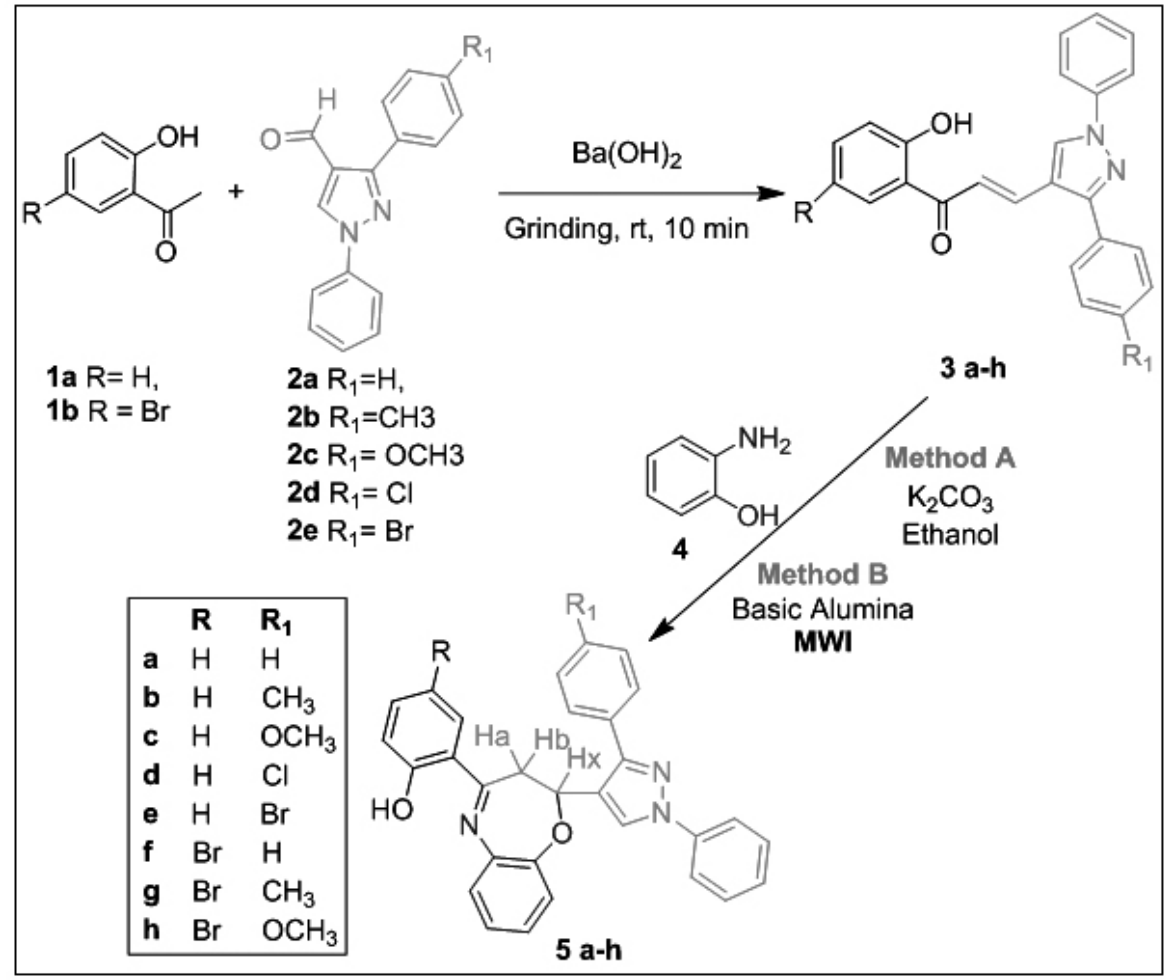

Scheme 1: Synthesis of pyrazole-chalcones (3a-h) and benzoxazepines (5a-h)

2-((E)-2,3-dihydro-2-(3-(4-methoxyphenyl)-1-phenyl-1H-pyrazol-4-yl) benzo[b][1,4]oxazepin-4-yl)phenol $(5 c)$

White solid; IR spectrum, $v \mathrm{~cm}^{-1}: 3142(\mathrm{OH}), 1600(\mathrm{C}=\mathrm{N}), 1239(\mathrm{C}-\mathrm{O}-\mathrm{C})$ ${ }^{1} \mathrm{HNMR}$ spectrum, $\delta$, ppm: $8.11(\mathrm{~s}, 1 \mathrm{H}$, pyrazole-H $), 7.98-6.98(\mathrm{~m}, 17 \mathrm{H}, \mathrm{Ar}-$ $\mathrm{H}), 5.65\left(\mathrm{dd}, 1 \mathrm{H}, J_{\mathrm{XB}}=12.4 \mathrm{H}_{\mathrm{Z}}, J_{\mathrm{XA}}=2.8 \mathrm{H}_{\mathrm{Z}}\right), 3.86\left(\mathrm{~s}, 3 \mathrm{H}, \mathrm{OCH}_{3}\right), 3.23(\mathrm{dd}, 1 \mathrm{H}$, $\left.J_{\mathrm{BA}}=16.8 \mathrm{H}_{\mathrm{z}}, J_{\mathrm{BX}}=12 \mathrm{H}_{\mathrm{z}}\right), 3.01\left(\mathrm{dd}, 1 \mathrm{H}, J_{\mathrm{B}}=16.8 \mathrm{H}_{\mathrm{z}} J_{\mathrm{AX}}=2.8 \mathrm{H}_{\mathrm{z}}\right) \cdot{ }^{13} \mathrm{CNMR}$ spectrum, $\delta$, ppm: 163.7, 161.2, 160.1, 153.7, 151.8, 140.1, 135.9, 129.6, $129.3,127.1,126.6,125.4,121.6,119.4,119.2,118,114.3,72.3,55.3,43.5$, 29.5. Found, \%: C 76.40, H 5.18, N 8.67. $\mathrm{C}_{31} \mathrm{H}_{25} \mathrm{~N}_{3} \mathrm{O}_{3}$. Calculated, \%: C 76.37 H 5.17; N 8.62. MS: $488[\mathrm{M}+\mathrm{H}]^{+}$.
2-((E)-2-(3-(4-chlorophenyl)-1-phenyl-1H-pyrazol-4-yl)-2,3dihydrobenzo[b][1,4]oxazepin-4-yl) phenol $(5 d)$

White solid; IR spectrum, $v \mathrm{~cm}^{-1}: 3141(\mathrm{OH}), 1602(\mathrm{C}=\mathrm{N}), 1229(\mathrm{C}-\mathrm{O}-\mathrm{C})$. ${ }^{1} \mathrm{HNMR}$ spectrum, $\delta$, ppm: $8.13(\mathrm{~s}, 1 \mathrm{H}$, pyrazole-H), 7.99-7.06 (m, 17H, Ar$\mathrm{H}), 5.65\left(\mathrm{dd}, 1 \mathrm{H}, J_{\mathrm{XB}}=12 \mathrm{H}_{\mathrm{Z}}, J_{\mathrm{XA}}=3.2 \mathrm{H}_{\mathrm{z}}\right) 3.26\left(\mathrm{dd}, 1 \mathrm{H}, J_{\mathrm{BA}}=14.2, J_{\mathrm{BX}}=12 \mathrm{H}_{\mathrm{z}}\right)$, $3.03\left(\mathrm{dd}, 1 \mathrm{H}, J_{\mathrm{B}}=14.2 \mathrm{H}_{\mathrm{z}} J_{\mathrm{XX}}=3.2 \mathrm{H}_{\mathrm{z}}\right) .{ }^{13} \mathrm{CNMR}$ spectrum, $\delta$, ppm: 160.9 $150.8,139.8,136.1,134.6$, 131.3, 129.6. 129.4, 128.8, 127,1, 126.9, 121.8 $121.2,119.4,119.3,117.9,71.9,43.3$. Found, \%: C 73.21; H 4.48; N 8.57. $\mathrm{C}_{30} \mathrm{H}_{22} \mathrm{ClN}_{3} \mathrm{O}_{2}$. Calculated, \%: C 73.24; $\mathrm{H} 4.51 ; \mathrm{N}$ 8.54. MS: $492[\mathrm{M}+\mathrm{H}]^{+}$. 
2-((E)-2-(3-(4-bromophenyl)-1-phenyl-1H-pyrazol-4-yl)-2,3dihydrobenzo[b][1,4]oxazepin-4-yl) phenol (5e)

White solid; IR spectrum, $v \mathrm{~cm}^{-1}$ : $3140(\mathrm{OH}), 1604(\mathrm{C}=\mathrm{N}), 1225(\mathrm{C}-\mathrm{O}-\mathrm{C})$. 'HNMR spectrum, $\delta$, ppm: 8.13 (s, 1H, pyrazole- $\mathrm{H}), 7.99-7.05(\mathrm{~m}, 17 \mathrm{H}$, Ar-H), $5.66\left(\mathrm{dd}, 1 \mathrm{H}, J_{\mathrm{XB}}=12.4 \mathrm{H}_{\mathrm{Z}}, J_{\mathrm{XA}}=3.2 \mathrm{H}_{\mathrm{Z}}\right), 3.23\left(\mathrm{dd}, 1 \mathrm{H}, J_{\mathrm{BA}}=16.8 \mathrm{H}_{\mathrm{Z}}\right.$, $\left.J_{\mathrm{BX}}=12.4 \mathrm{H}_{\mathrm{z}}\right), 3.03\left(\mathrm{dd}, 1 \mathrm{H}, J_{\mathrm{AB}}=16.8 \mathrm{H}_{7} J_{\mathrm{A}}=3.2 \mathrm{H}_{\mathrm{z}}\right) \cdot{ }^{13} \mathrm{CNMR}$ spectrum, $\delta$, ppm: $160.9,150.9,139.8,136.1,131.8,129.9,129.4,127.1,127,122.7,121.8$ 121.2, 119.4, 119.3, 118, 71.9, 43.3, 29.6. Found, \%: C 67.51; H 3.57; N 7.86. $\mathrm{C}_{30} \mathrm{H}_{22} \mathrm{BrN}_{3} \mathrm{O}_{2}$. Calculated, \%: C 67.17; H 4.13; N 7.83. MS: $535[\mathrm{M}]^{+}, 537$ $[\mathrm{M}+2]^{+}$.

4-bromo-2-((E)-2,3-dihydro-2-(1,3-diphenyl-1H-pyrazol-4-yl)benzo[b] [1,4]oxazepin-4-yl)phenol (5f)

White solid; IR spectrum, $v \mathrm{~cm}^{-1}: 3402(\mathrm{OH}), 1600(\mathrm{C}=\mathrm{N}), 1238(\mathrm{C}-\mathrm{O}-\mathrm{C})$. ${ }^{1} \mathrm{HNMR}$ spectrum, $\delta$, ppm: 8.09 (s, 1H, Pyrazole-H), 7.78-6.97 (m, 17H, Ar$\mathrm{H}), 5.64\left(\mathrm{dd}, 1 \mathrm{H}, J_{\mathrm{XB}}=12 \mathrm{H}_{\mathrm{Z}}, J_{\mathrm{XA}}=3.2 \mathrm{H}_{\mathrm{Z}}\right), 3.21\left(\mathrm{dd}, 1 \mathrm{H}, J_{\mathrm{BA}}=16.8 \mathrm{H}_{\mathrm{Z}}, J_{\mathrm{BX}}=12 \mathrm{H}_{\mathrm{Z}}\right)$, $3.02\left(\mathrm{dd}, 1 \mathrm{H}, J_{\mathrm{AB}}=16.8 \mathrm{H}_{\mathrm{z}} J_{\mathrm{AX}}=3.2 \mathrm{H}_{\mathrm{z}}\right) \cdot{ }^{13} \mathrm{CNMR}$ spectrum, $\delta_{\mathrm{C}}, \mathrm{ppm}: 160,158$, 154.6, 151, 141.1, 130.4, 129.4, 129.3, 127.5, 126.4, 125.8, 125.5, 122.3, 119 , 116.7, 114.3, 70.1, 40.88. Found, \%: C 67.14; $\mathrm{H} 4.11 ; \mathrm{N}$ 7.86. $\mathrm{C}_{30} \mathrm{H}_{22} \mathrm{BrN}_{3} \mathrm{O}_{2}$. Calculated, \%: C 67.17; H 4.13; N 7.83. MS: $535[\mathrm{M}]^{+}, 537[\mathrm{M}+2]^{+}$.

4-bromo-2-((E)-2,3-dihydro-2-(1-phenyl-3-p-tolyl-1H-pyrazol-4-yl) benzo[b][1,4]oxazepin-4-yl) phenol (5g)

White solid; IR spectrum, $v \mathrm{~cm}^{-1}: 3137(\mathrm{OH}), 1602(\mathrm{C}=\mathrm{N}), 1210(\mathrm{C}-\mathrm{O}-\mathrm{C})$. ${ }^{1} \mathrm{HNMR}$ spectrum, $\delta$, ppm: 8.14'(s, 1H, Pyrazole-H), 7.81-6.98 (m, 16H, Ar-H), $5.64\left(\mathrm{dd}, 1 \mathrm{H}, J_{\mathrm{XB}}=12.4 \mathrm{H}_{\mathrm{Z}}, J_{\mathrm{XA}}=2.8 \mathrm{H}_{\mathrm{z}}\right), 3.21\left(\mathrm{dd}, 1 \mathrm{H}, J_{\mathrm{BA}}=16.8 \mathrm{H}_{\mathrm{Z}}, J_{\mathrm{BX}}=12.4 \mathrm{H}_{\mathrm{z}}\right)$, $2.99\left(\mathrm{dd}, 1 \mathrm{H}, J_{\mathrm{AB}}=16.8 \mathrm{H}_{\mathrm{Z}} J_{\mathrm{AX}}=2.8 \mathrm{H}_{\mathrm{z}}\right), 2.36\left(\mathrm{~s}, 3 \mathrm{H}, \mathrm{CH}_{3}\right) .{ }^{13} \mathrm{CNMR}$ spectrum, $\delta_{\mathrm{C}}$, ppm: $159.2,151.9,140,137.1,132.8,131.2,129.3,128.5,128.4,128.3$, $126.7,126.6,120.9,119.7,119.3,117.8,72.1,43.6,20.2$. Found, \%: C 67.61; $\mathrm{H} 4.35 ; \mathrm{N}$ 7.67. $\mathrm{C}_{31} \mathrm{H}_{24} \mathrm{BrN}_{3} \mathrm{O}_{2}$. Calculated, \%: C 67.64; $\mathrm{H} 4.39 ; \mathrm{N}$ 7.63. MS: $549[\mathrm{M}]^{+}, 551[\mathrm{M}+2]^{+}$.

4-bromo-2-((E)-2,3-dihydro-2-(3-(4-methoxyphenyl)-1-phenyl-1Hpyrazol-4-yl)benzo [b] [1,4] oxazepin-4-yl)phenol (5h)

White solid; IR spectrum, $v \mathrm{~cm}^{-1}: 3135(\mathrm{OH}), 1598(\mathrm{C}=\mathrm{N}), 1209(\mathrm{C}-\mathrm{O}-\mathrm{C})$. ${ }^{1} \mathrm{HNMR}$ spectrum, $\delta$, ppm: 8.09 (s, 1H, Pyrazole-H) 8.08-6.93 (m, 16H, Ar$\mathrm{H}), 5.64\left(\mathrm{dd}, 1 \mathrm{H}, J_{\mathrm{XB}}=11.6 \mathrm{H}_{\mathrm{Z}}, J_{\mathrm{XA}}=3.2 \mathrm{H}_{\mathrm{z}}\right), 3.86\left(\mathrm{~s}, 3 \mathrm{H}, \mathrm{OCH}_{3}\right), 3.21(\mathrm{dd}, 1 \mathrm{H}$, $\left.J_{\mathrm{BA}}=16.8 \mathrm{H}_{\mathrm{z}}, J_{\mathrm{BX}}=11.6 \mathrm{H}_{\mathrm{z}}\right), 3.02\left(\mathrm{dd}, 1 \mathrm{H}, J_{\mathrm{AB}}=16.8 \mathrm{H}_{\mathrm{z}} J_{\mathrm{AX}}=3.2 \mathrm{H}_{\mathrm{z}}\right) .{ }^{13} \mathrm{CNMR}$ spectrum, $\delta_{\mathrm{C}}$, ppm: $152.96,150.87,147.5,139.69$, 134.33, 133.69, 131.58, $129.82,129.53,128.84,126.91,126.11,125.05,124.30,122.67,119.19$, 112.85, 70.3, 43.4, 29.7. Found, \%: C 65.70; $\mathrm{H} 4.25 ; \mathrm{N}$ 7.46. $\mathrm{C}_{31} \mathrm{H}_{24} \mathrm{BrN}_{3} \mathrm{O}_{3}$. Calculated, \%: C 65.73; H 4.27; N 7.42. MS: $565[\mathrm{M}]^{+}, 567[\mathrm{M}+2]^{+}$.

\section{BIOLOGICAL ASSAY}

Antibacterial activity

The synthesized novel compounds 3a-h, 5a-g were screened for their Antibacterial activity against different types of bacterial strains, they are Gram positive bacterial strains of Bacillus subtilis and Staphylococcus aeureus, Gram negative bacterial strains of Pseudomonas aeruginosa and Escherichia coli, at a concentration of $50 \mu \mathrm{g} / \mathrm{mL}$. The cultures were diluted with $5 \%$ autoclaved saline and the final volume was made with concentration approximately $10^{5}-10^{6} \mathrm{CFU} / \mathrm{mL}$. The synthesized compounds were diluted in acetone for antibacterial biological assays. For agar disc diffusion method ${ }^{30}$, the liquid form of test compound was soaked on to the disc and then allowed to air dry, such that the disc gets completely saturated with test compound. The saturated chemical discs were introduced onto the upper layer of the medium evenly loaded with the bacteria.

The discs were dipped in different chemical samples, were placed over the evenly spread bacterial nutrient media and incubated at $37^{\circ} \mathrm{C}$ for 24 to $48 \mathrm{~h}$ for better inhibition of bacteria. The zones of inhibition were measured after 24 to $48 \mathrm{~h}$. All the experiments were carried out in triplicates and the results were expressed as zone of Inhibition in $\mathrm{mm}$. The zones of inhibition of synthesized compounds $\mathbf{3 a - h}, \mathbf{5 a}-\mathbf{h}$ were compared with the zone of inhibition of standard antibiotic concentration of Ampicillin $(50 \mu \mathrm{g} / \mathrm{mL})$. The Antibacterial activity was evaluated and the results are presented in Table 2.
Table 2: Antibacterial activity of compounds $\mathbf{3 a}-\mathbf{h}$ and $\mathbf{5 a}-\mathbf{h}$

\begin{tabular}{|c|c|c|c|c|}
\hline \multirow{3}{*}{ Compound } & \multicolumn{4}{|c|}{ Zone of Inhibition, mm } \\
\hline & \multicolumn{2}{|c|}{ Gram-positive bacteria } & \multicolumn{2}{|c|}{ Gram-negative bacteria } \\
\hline & $\begin{array}{c}\text { Staphylococcus } \\
\text { aureus }\end{array}$ & $\begin{array}{c}\text { Bacillus } \\
\text { subtilis }\end{array}$ & $\begin{array}{c}\text { Pseudomonas } \\
\text { aeruginosa }\end{array}$ & $\begin{array}{c}\text { Escherichia } \\
\text { coli }\end{array}$ \\
\hline $3 \mathbf{a}$ & 23 & 05 & 04 & 10 \\
\hline $3 b$ & 24 & 10 & 08 & 25 \\
\hline $3 c$ & 30 & 12 & 09 & 32 \\
\hline 3d & 22 & 07 & 08 & 25 \\
\hline $3 \mathbf{e}$ & 12 & 04 & 03 & 12 \\
\hline $3 f$ & 10 & 08 & 02 & 23 \\
\hline $3 g$ & 22 & 10 & 07 & 22 \\
\hline $3 \mathbf{h}$ & 28 & 12 & 11 & 29 \\
\hline $5 \mathbf{a}$ & 22 & 08 & 05 & 17 \\
\hline $5 \mathbf{b}$ & 27 & 10 & 08 & 28 \\
\hline $5 c$ & 28 & 11 & 08 & 32 \\
\hline $5 d$ & 20 & 07 & 05 & 22 \\
\hline $5 e$ & 18 & 10 & 08 & 21 \\
\hline $5 f$ & 15 & 09 & 06 & 18 \\
\hline $5 g$ & 28 & 11 & 09 & 28 \\
\hline $5 \mathbf{h}$ & 32 & 11 & 10 & 28 \\
\hline Ampicillin & 30 & 12 & 10 & 30 \\
\hline
\end{tabular}

Antifungal activity

The antifungal activity of synthesized compounds $\mathbf{3 a - h}, \mathbf{4 a - h}$ was tested against three pathogenic fungi, namely Aspergillus niger, Penicillium italicum, and Fusarium oxysporum, by the poison plate technique ${ }^{31}$ at a concentration of $50 \mu \mathrm{g} / \mathrm{mL}$. Three kinds of fungi were incubated in PDA at $25 \pm 1{ }^{\circ} \mathrm{C}$ for 5 days to get new mycelium for antifungal assay, then a mycelia as disks of approximately $0.45 \mathrm{~cm}$ diameter cut from the culture medium were picked up with a sterilized inoculation needle and inoculated in the center of PDA plate. Test compounds were dissolved in acetone $(10 \mathrm{~mL})$ then added to the Potato Dextrose Agar medium (PDA, $90 \mathrm{~mL}$ ). The final concentration of compounds in the medium was adjusted to $50 \mu \mathrm{g} / \mathrm{mL}$. The inoculated plates were incubated at $25 \pm 1{ }^{\circ} \mathrm{C}$ for 5 days. Acetone was diluted with sterilized distilled water and used as control, while Grieseofulvin $(50 \mu \mathrm{g} / \mathrm{mL})$ was used as standard control for each treatment three replicates of experiments were carried out. The radial growth of the fungal colonies was measured on the sixth day. The Antifungal activity was evaluated and the results are presented in Table 3.

\section{RESULTS AND DISCUSSION}

Chemistry

Several synthetic methodologies are available for the synthesis of chalcones. Generally the condensation of acetophenone with aldehyde in the presence of basic media is widely used. By keeping the view in green methods we have selected to synthesize an efficient solvent free synthesis of chalcones by grinding equimolar quantities of 2-hydroxy acetophenone and substituted pyrazole aldehyde in the presence of $\mathrm{Ba}(\mathrm{OH})_{2}$, at room temperature for $10 \mathrm{~min}$. Further, these pyrazole-chalcones $(\mathbf{3 a - h})^{32,33}$ on thermal cyclization with 2-aminophenol in the presence of basic alumina under microwave irradiation $^{34,35}$ resulted benzoxazepines (5a-h) in good yields (Scheme 1). All the reactions were carried out using microwave irradiations in 9-12 min., while same reactions under conventional condition, the time period required for the completion of the reaction was quite long and gave moderate yields. Hence, the microwave assisted synthesis bids clean and cheaper alternative path to that of conventional heating, indicating that the microwave irradiation simplifies the polarization of molecules producing reaction to occur at shorter reaction times in good yields. The use of microwave irradiation in present investigation gave $80-88 \%$ yields of product, whereas moderate yields were obtained by conventional methods. All the synthesized compounds were characterized by ${ }^{1} \mathrm{H}$ NMR, ${ }^{13} \mathrm{C}$ NMR, Mass and IR spectral data. 
Table 3: Antifungal activity of Compounds 3a-h and 5a-h.

\begin{tabular}{|c|c|c|c|}
\hline \multirow[b]{2}{*}{ Compound } & \multicolumn{3}{|c|}{ Zone of Inhibition, $\mathrm{mm}$} \\
\hline & $\begin{array}{c}\text { Aspergillus } \\
\text { nigerzeae }\end{array}$ & $\begin{array}{c}\text { Penicillium } \\
\text { italicum }\end{array}$ & $\begin{array}{l}\text { Fusarium } \\
\text { oxysporum }\end{array}$ \\
\hline $3 \mathbf{a}$ & 08 & 16 & 22 \\
\hline $3 \mathbf{b}$ & 12 & 21 & 25 \\
\hline $3 c$ & 11 & 20 & 23 \\
\hline 3d & 09 & 20 & 26 \\
\hline $3 \mathbf{e}$ & 12 & 24 & 28 \\
\hline $3 f$ & 09 & 21 & 23 \\
\hline $3 g$ & 06 & 18 & 23 \\
\hline $3 \mathbf{h}$ & 11 & 21 & 24 \\
\hline $5 \mathbf{a}$ & 15 & 25 & 28 \\
\hline $5 b$ & 08 & 14 & 19 \\
\hline $5 c$ & 14 & 21 & 24 \\
\hline $5 d$ & 07 & 15 & 18 \\
\hline $5 e$ & 06 & 12 & 14 \\
\hline $5 f$ & 08 & 10 & 10 \\
\hline $5 \mathrm{~g}$ & 14 & 21 & 23 \\
\hline $5 h$ & 13 & 22 & 24 \\
\hline Grieseofulvin & 12 & 20 & 25 \\
\hline
\end{tabular}

Biological activities

Antibacterial activity

All the compounds were screened for their antibacterial activity agains Staphylococcus aureus, Bacillus subtilis, Pseudomonas aeruginosa and Escherichia coli using Ampicillin as standard drug. The activity was determined using cup plate agar diffusion method by measuring the zone of inhibition in $\mathrm{mm}$ (Table 2). The compounds were screened at the concentration of $50 \mu \mathrm{g} /$ $\mathrm{ml}$ in DMSO. From the screening studies it is evident that the synthesized compounds 3c, $\mathbf{3 h}, \mathbf{5 b}, \mathbf{5 c}, \mathbf{5} \mathbf{g}$ and $\mathbf{5 h}$ showed good antibacterial activity against all the tested organisms, which shows that the electron releasing groups enhanced the antibacterial activity. Furthermore, methoxy (3c), bromo methoxy (3h), methyl (5b), methoxy (5c), bromo methyl (5g), and bromo methoxy (5h) group derivatives are potentially active.

Antifungal activity:

All the compounds were screened for their antifungal activity against Aspergillus nigerzeae, Penicillium italicum and Fusarium oxysporum using Grieseofulvin as standard drug. The activity was determined using cup plate agar diffusion method by measuring the zone of inhibition in $\mathrm{mm}$. The compounds were screened at the concentration of $50 \mu \mathrm{g} / \mathrm{ml}$ in DMSO. From the screening studies it is evident that the synthesized compounds $\mathbf{3 b}, \mathbf{3 c}, \mathbf{3 e}$, $\mathbf{3 h}, \mathbf{5 a}, \mathbf{5 c}, \mathbf{5}$ g and $\mathbf{5 h}$ showed good antifungal activity against all the tested organisms. However, in the case of the remaining compounds, the activity doesn't depend much on the electronic nature of the compounds (Table 3).

\section{CONCLUSIONS}

In summary, we have demonstrated an efficient, economical, environmentally benign, and rapid process for the synthesis of benzoxazepines derivatives from pyrazole-chalcones reaction with 2-amino phenol. It was discovered that microwave-assisted method is highly efficient procedure for the preparation of benzoxazepines, especially in the solvent-free media. This method eliminates the use of $\mathrm{K}_{2} \mathrm{CO}_{3}$ and ethanol solvent. No additional base and solvent are required as basic alumina acts as solid support and base. Additionally, application of microwave decreases the time of the reaction extensively with a better-quality yield of the product. The uniqueness of the methodology lies in its eco-friendly operation, with excellent yield. In this study, a new hybrid molecules consisting of biologically important benzoxazepine derivatives (5a-h) from pyrazole-chalcones (3a-h) pharmacophores were synthesized and their antibacterial and antifungal activities were determined. Amongst the synthesized compounds, $\mathbf{3 c}, \mathbf{3 h}, \mathbf{5 b}, \mathbf{5 c}, \mathbf{5} \mathbf{g}$ and $\mathbf{5 h}$ showed good antibacterial activity. The antifungal activity of the synthesized compounds also showed that compounds $\mathbf{3 b}, \mathbf{3 c}, \mathbf{3 e}, \mathbf{3 h}, \mathbf{5 a}, \mathbf{5 c}, \mathbf{5 g}$ and $\mathbf{5 h}$ have good inhibition values. The experimental results of this study will likely provide a new basis for the design of interesting pyrazole-chalcones based benzoxazepine, and further studies, including the design of new analogs of the heterocyclic moiety, are underway.

\section{ACKNOWLEDGEMENTS}

The authors are grateful to Head, Department of Chemistry, Osmania University, Hyderabad for providing laboratory facilities. Authors are also thankful to DST, PURSE-II Programme, Osmania University for the Financial assistance.

\section{REFERENCES}

[1] E. Rohrmann, R.G. Jones, H.A. Shonle, J. Am. Chem. Soc., 66, 1856 (1944).

[2] G. Pasquale, G.P. Romanelli, J.C. Autino, J. García, E.V. Ortiz, P.R. Duchowicz, J. Agric. Food Chem., 60, 692, (2012).

[3] V. Monga, K. Goyal, M. Steindel, M. Malhotra, D.P. Rajani, S.D. Rajani, Med. Chem. Res., 23, 2019, (2014).

[4] F.E. Hawaiz, M.K. Samad, J. Chem., 3, 1613, (2012).

[5] K.A. Parmar, J.R. Vihol, Y.M. Dabhi, S.D. Sutariya, J. Chem. Pharm Res., 4, 1584, (2012)

[6] O.A. Miqdad, N.M. Abunada, H.M. Hassaneen, A.S.M.A. Samaha, Int. J Chem., 3, 20, (2011).

[7] V. Gressler, S. Moura, A.F.C. Flores, D.C. Flores, P. Colepicolo, E. Pinto, J. Braz. Chem. Soc., 21, 1477, (2010)

[8] M.A. Ali, M. Shaharyar, Bioorg. Med. Chem., 15, 1896, (2007).

[9] M. Shaharyar, A.A. Siddiqui, Bioorg. Med. Chem. Lett., 16, 3974, (2006)

[10] S. Bano, K. Javed, S. Ahmad, I.G. Rathish, S. Singh, M.S. Alam, Eur. J. Med. Chem., 46, 5763, (2001)

[11] K.M. Amin, S.M. Abou-Seri, F.M. Awadallah, A.A.M. Eissa, G.S. Hassan M.M. Abdulla, Eur. J. Med. Chem., 90, 221, (2015).

[12] N.M.M. Moura, C. Nunez, S.M. Santos, M.A.F. Faustino, J.A.S. Cavaleiro, M.G.P.M.S. Neves, J.L. Capelo, C. Lodeiro, Inorg. Chem.,53, 6149, (2014).

[13] B.F. Abdel-Wahab, H. Abdel-Gawad, G.E.A. Awad, F.A. Badria, Med Chem. Res., 1418, (2012).

[14] Y. Xia, Z.W. Dong, B.X. Zhao, X. Ge, N. Meng, D.S. Shin, J.Y. Miao, Bioorg. Med. Chem., 15, 6893, (2007).

[15] O.I. EI-Sabbagh, M.M. Baraka, S.M. Ibrahim, C. Pannecouque, G Andrei, R. Snoeck, J. Balzarini, A.A. Rashad, Eur. J. Med. Chem., 44, 3746, (2009).

[16] C.N. Khobragade, R.G. bodade, B.S. Dawane, S.G. Konda, N.T Khandare, J. Enzym. Inhib. Med. Chem., 25, 615, (2010).

[17] S. Sidique, R. Ardecky, Y. Su, S. Narisawa, B. Brown, J.L. Mill-an, E Sergienko, N.D.P. Cosford, Bioorg. Med. Chem. Lett., 19, 222, (2009).

[18] J.F. Liegeois, M. Deville, S. Dilly, C. Lamy, F. Mangin, M. Resimont, F.I. Tarazi, J. Med. Chem., 5,1572, (2012).

[19] C.G. Neochoritis, C.A. Tsoleridis, J.S. Stephanatou, C.A. Kontogiorgis, D.J. Hadjipavlou-Litina, J. Med. Chem., 53, 8409, (2010).

[20] J.F. Liegeois, M. Deville, S. Dilly, C. Lamy, F. Mangin, M. Resimont, F.I Tarazi, J. Med. Chem., 55, 1572, (2012).

[21] B. Capuano, I.T. Crosby, F.M. McRobb, D.A. Taylor, A. Vom, W.W Blessing, Prog. Neuropsychopharmacol. Biol. Psychiatry, 34, 136, (2010).

[22] C.S. Takeuchi, B.G. Kim, C.M. Blazey, S. Ma, H.W.B. Johnson, N.K Anand, A. Arcalas, T.G. Baik, C.A. Buhr, J. Cannoy, S. Epshteyn, A. Joshi, K. Lara, M.S. Lee, L. Wang, J.W. Leahy, J.M. Nuss, N. Aay, R. Aoyama, P. Foster, J. Lee, I. Lehoux, N. Munagala, A. Plonowski, S. Rajan, J. Woolfrey, K. Yamaguchi, P. Lamb, N. Miller, J. Med. Chem., 56, 2218, (2012).

[23] Y.L. Zhou, S.W. Shen, F.M. Liu, J. Heterocycl. Chem., 48, 105, (2011)

[24] N.D. Adhikary, P. Chattopadhyay, Eur. J. Org. Chem., 7346, (2011).

[25] P. Thansandote, E. Chong, K.O. Feldmann, M. Lautens, J. Org. Chem., 75, 3495, (2010).

[26] M. Larhed, C. Moberg, A. Hallberg, Acc. Chem. Res., 35, 717, (2002).

[27] S. Sarkar, S. Dutta, A.K. Sen, Synthesis 44, 1079, (2012).

[28] R. Pal, S. Sarkar, N. Chatterjee, A.K. Sen, Tetrahedron Lett., 54, 5642 , (2013)

[29] P. Saha, S. Naskar, P. Paira, A. Hazra, K.B. Sahu, R. Paira, S. Banerjee, 
N.B. Mondal, Green Chem. 11, 931, (2009).

[30] H. J. Benson, Microbiological Applications, Boston, MA, U. S. A., W. C. Brown Publications, (1990).

[31] K. Saha, K. Mukherjee Pulok, S. C. Mandal, M. Pal, B. P. Saha, Indian Drugs, 32, 402, (1995).

[32] D. Ashok, G. Radhika, Indian J. Heterocycl. Chem., 20(3), 291, (2011).
33] D. Ashok, A. Ganesh, V.B. Lakshmi, S. Ravi, Russ. J. Gen. Chem., 85(9), 2141, (2015).

[34] D. Ashok, D. Shravani, M. Sarasija, K. Sudershan, Russ. J. Gen. Chem. 85(5), 1152, (2015)

[35] D. Ashok, G. Sriniva, V.A. Kumar, D.M. Gandhi, M.S. Reddy, Russ. J. Gen. Chem., 85(3), 708, (2015). 